\title{
Evaluation of biopathogenesis of meningioma cases in the light of literature
}

\section{Meningiom olgularının biyopatogenezinin literatür eşliğinde değerlendirilmesi}

\author{
Numan KARAARSLAN ${ }^{1}$, Mehmet Sabri GÜRBÜZ ${ }^{2}$, Abdullah Talha ŞiMŞEK ${ }^{1}$, Mehmet ERŞAHIN ${ }^{2}$, \\ Mehmet Zafer BERKMAN ${ }^{3}$
}

ABSTRACT

In this study, it was aimed to investigate the bio pathogenesis of the cases diagnosed with meningioma in the light of the literature. The patients $(n=79)$ operated due to the meningioma in neurosurgery department between 2005 and 2010 were retrospectively examined. Findings that may affect the biological behavior and prognosis of the tumours recorded in these reported data were evaluated. A total of 79 cases meeting the research criteria were included in the study. When the histopathological grade of the cases was examined, it was seen that 59 cases (74.7\%) were grade I and 20 cases (25.3\%) were grade II. When the relation between the localization and histological grade of the cases was examined, it was determined that the meningiomas were most frequently located in convexity and that most of grade II cases were localized at this site. Preoperative peritumoral oedema was found to be more prevalent, especially in the sphenoid wing and convexity meningiomas. A total of 9 cases of recurrence (11.4\%) occurred during follow-up period. When carrying out evaluation between surgical resection grade and recurrent cases, it was detected that all cases where it was performed Simpson grade IV and Kobayashi grade IVA and IVB resection had a recurrence. When the localization of recurrent cases was examined, it was seen that 4 cases (\%44.4) were sphenoid wing meningioma, 2 cases (\%22.2) were parasagittal meningioma, 1 case (\%11.1) was tuberculosis sellae meningioma and 1 case (\%11.1) was intraventricular meningioma. In our study, histopathologic subtype and surgical resection grade were found to play a significant role in prognosis in meningiomas. It was also thought that the presence of peritumoral oedema and tumour localization could affect the biological behavior and prognosis of the meningioma. Findings obtained should be supported by multi-center studies that will include the cases of different races with more series.

Keywords: Biopathogenesis, histopathology, meningioma
Öz

Bu araştırmada, meningiom tanılı olgularının biyopatogenezi literatür eşliğinde araştırılması amaçlandı. Nöroşirurji Kliniğinde, 2005 ile 2010 yılları arasında meningiom nedeniyle opere edilmiş olan olgular $(n=79)$ geriye dönük olarak incelendi. Dosya arşiv taraması sonrasında elde edilen demografik veriler ile kan grubu, sigara kullanımı, meningiom lokalizasyonu, peritümöral ödem, Simpson ve Kobayashi rezeksiyon derecesi, histotolojik alt tip, grade, nüks bilgilerine ait klinik veriler, kayıt altına alındı. $R a-$ porlanan bu veriler içerisinde kaydedilen tümörlere ait biyolojik davranış ve prognozuna etki edebilecek bulgular değerlendirildi. Araştırma kriterlerini karşılayan toplam 79 olgu çalışmaya dâhil edildi. Olguların histopatolojik grade incelendiğinde, $59(\% 74,7)$ olgunun grade l; 20 (\%25,3) olgunun grade II olduğu görüldü. Olguların lokalizasyonu ve histolojik grade ilişkisine bakıldığında, meningiomların en sık konveksitede yerleştiği ve grade II olguların çoğunun bu lokalizasyonda olduğu saptandı. Preoperatif peritümöral ödemin, özellikle sfenoid kanat ve konveksite meningiomlarında daha fazla olduğu saptandı. Olguların takipleri sırasında toplam $9(\% 11,4)$ olguda nüks görüldü. Cerrahi rezeksiyon derecesi ile nüks olgular arasında yapılan değerlendirmede Simpson grade IV ve Kobayashi grade IVA ve IVB rezeksiyon yapılan olguların tümünde nüks saptandı. Nüks olgular ile histopatolojik alt tip arasındaki ilişki incelendiğinde nüks eden $7(\% 77,7)$ olgunun grade II, 2 (\%33,3) olgunun ise grade I meningiom olduğu saptandı. Nüks olguların lokalizasyonu incelendiğinde, 4 $(\% 44,4)$ olgu sfenoid kanat, 2'si $(\% 22,2)$ parasagittal, 1'i $(\% 11,1)$ tuberkulum sella, 1'i $(\% 11,1)$ ise intraventriküler yerleşimliydi. Çalışmamızda, meningiomlarda histopatalojik alt tip ve cerrahi rezeksiyon derecesinin prognozda önemli rol oynadığı saptandı. Ayrıca tümör lokalizasyonunun ve peritümöral ödem varlığının meningioma prognozunda ve biyolojik davranışa etki edebileceği düşünüldü. Elde edilen bulguların, ileriye yönelik, farklı ırkların yer alacağı, çok merkezli ve daha fazla serileri içeren olguların yer alacağı çalışmalarla desteklenmesi gerekmektedir.

Anahtar kelimeler: Biyopatogenez, histopatoloji, meningiom

Received: 24.12 .2017

Accepted: 13.03 .2018

${ }^{1}$ Namık Kemal Üniversitesi, Tıp Fakültesi, Nöroşirürji Anabilim Dalı, Tekirdağ, Türkiye

${ }^{2}$ Īstanbul Medeniyet Üniversitesi, Tıp Fakültesi, Nöroşirürji Anabilim Dalı, İstanbul, Türkiye

${ }^{3}$ Acıbadem Hastanesi, Nöroşirürji Kliniği, İstanbul, Türkiye

Yazışma adresi: Yrd. Doç. Dr. Mehmet Sabri Gürbüz, Eğitim Mah. Dr. Erkin Cad. 34722 - İstanbul - Türkiye

e-mail: mehmetsabrigurbuz@gmail.com 


\section{GiRiş}

Meningiomlar, merkezi sinir sisteminin en sık görülen, glial olmayan primer beyin tümörleridir. Etiyolojisinde kanıtlanmış olan radyasyona maruziyet dışında kesin kanıtlar olmamakla birlikte, başta viral etkenler olmak üzere, kişinin yaşam tarzı ve genetik yapısına ait faktörlerin etkili olduğunu bildiren araştırmalar literatürde yer almaktadır ${ }^{1}$. Biyolojik davranış yönünden genelde benign karakterdeki tümörlerdir. Fakat bazı meningiom alt tipleri histopatolojik olarak benign olmalarına rağmen, agresif karakter gösterebilirler. Dolayısıyla meningiomların davranış paterninin önceden bilinmesi her zaman olası değildir².

Literatürde, tümör dokusunun biyopatogenezi üzerine çalışmalar yapılmasına karşın, özellikle lokalizasyonun, çevre dokulara invazyonun, yaş, cinsiyet ve cerrahi rezeksiyon derecesinin de etkin faktörler olduğu düşünülmektedir. Anılan bu faktörlerin biyopatogenez dışında prognoz ile de yakın ilişkisi olduğu bildirilmektedir².

$\mathrm{Bu}$ araştırmada, meningiomların histolojik alt tipleri ve dereceleri, tümör grade ve biyopatogenezinin, üzerine etki eden faktörler ve bu faktörlerin prognoz ile ilişkisi araştırılarak, elde edilen bulguların, mevcut literatür ile tartışıması amaçlandı.

\section{GEREÇ ve YÖNTEM}

Gerekli izinler alındıktan sonra, 2005-2010 yılları arasında meningiom nedeniyle opere edilmiş 79 olgu retrospektif olarak incelendi. Olguların yas, cinsiyet, kan grubu, alkol-sigara kullanım öyküsü, meningiom lokalizasyonu, peritümöral ödem, Simpson ve Kobayashi cerrahi grade, meningiom histotolojik alt tipi, meningiom grade, nüks bilgileri, olgular ait arşiv dosyalarından alındı. Olgulara ait patolojik materyallerin, patoloji kliniği arşivinden elde edildiği ve patoloji laboratuvarında, olgulara ait parafin bloklardan hematoksilen-eozin boyalı kesitler elde edilerek preparatların, ışık mikroskobisi yardımı ile çeşitli büyütmelerde incelendiği anlaşıldı. Meningiomların histolojik alt tiplemesinin, Dünya Sağlık Örgütü sı- nıflamasına göre derecelendirildiği görüldü. Benign karakterdeki meningotelyal, fibroblastik, transizyonel, mikrokistik, psammomatöz, anjomatöz meningiomlar grade I olarak kabul edildiği, x10 büyütmede dört veya daha fazla mitotik hücre görülmesi ya da üç mitotik hücre görülmesinin, ayrıca selülarite artışı, küçük hücre formasyonu, nekroz, hücre çekirdeğinde belirginleşmesi, serebral invazyonun da eşlik ettiği meningiomların, grade II meningiom olarak kabul edildiği kaydedildi. Atipik, kordoid, berrak hücreli meningiomlar grade II meningiom grubunda değelendirildi.

Çalışmada elde edilen bulguların, istatistiksel analizleri için NCSS (Number Cruncher Statistical System) 2007\&PASS 2008 Statistical Software (Utah, USA) programı kullanıldı. Çalışmadaki niceliksel verilerin tanımlayıcı istatistikleri ortalama \pm standart sapma şeklinde, niceliksel olanlar ise yüzde frekansları kullanılarak özetlendi. Niteliksel verilerin karşılaştırılmasında ise ki-kare test ve Fisher's Exact ki-kare testlerinden faydalanıldı. $\mathrm{p}<0.05$ düzeyi istatistiksel olarak anlamlı kabul edildi.

\section{BULGULAR}

Çalışmaya dâhil edilen toplam 79 olgunun yaşlarının 23 ile 78 yıl arasında değiştiği ve ortalama 52,9 yıl olduğu hesaplandı. Olguların 56'sı $(\% 70,9)$ kadın, 23'ü $(\% 29,1)$ erkekti. Olguların histopatolojik grade incelendiğinde, $59(\% 74,7)$ olgunun grade I; $20(\% 25,3)$ olgunun grade II olduğu görüldü (Tablo 1 ).

Tablo 1. Olgulara ait histopatolojik tip ve derecelendirilmesi arasındaki ilişki.

\begin{tabular}{llll}
\hline Histopatolojik Tip & $\begin{array}{l}\text { Grade 1; } \\
\text { n (Frekans) }\end{array}$ & $\begin{array}{l}\text { Grade 2; } \\
\text { n (Frekans) }\end{array}$ & $\begin{array}{l}\text { Toplam; } \\
\text { n (Frekans) }\end{array}$ \\
\hline Anjiomatöz & $1(\% 1,7)$ & 0 & $1(1,3)$ \\
Atipik & 0 & $16(\% 80)$ & $16(\% 20,3)$ \\
Berrak Hücreli & 0 & $2(\% 10)$ & $2(\% 2,5)$ \\
Fibroblastik & $3(\% 5,1)$ & 0 & $3(\% 3,8)$ \\
Kordoid & 0 & $2(\% 10)$ & $2(\% 2,5)$ \\
Meningotelyal & $13(\% 22)$ & 0 & $13(\% 16,5)$ \\
Mikrokistik & $1(\% 7,1)$ & 0 & $1(\% 1,3)$ \\
Psamimomatöz & $2(\% 3,4)$ & 0 & $2(\% 2,5)$ \\
Transizyonel & $39(\% 66,1)$ & 0 & $39(\% 49,4)$ \\
Toplam & $59(\% 100)$ & $20(\% 100)$ & $79(\% 100)$ \\
& & & \\
\hline
\end{tabular}


Meningiomların lokalizasyonuna göre en sık konveksite, sfenoid kanat ve parasagittal bölgelerde sırası ile $\% 27,1(n=16) ; \% 20,3(n=12) ; \% 16,9(n=10)$ yerleşmiş olduğu raporlandı (Tablo 2 ).

Tablo 2. Olgular ait tümör lokalizasyonlarının derecelendirilmesi ile arasındaki ilişki.

\begin{tabular}{llll}
\hline & \multicolumn{2}{c}{ Histopatolojik Grade } & \\
\cline { 2 - 3 } Lokalizasyon & $\begin{array}{l}\text { Grade I } \\
\text { n (\%) }\end{array}$ & Grade II & p \\
\hline Falks & $4(\% 6,8)$ & $2(\% 10)$ & 0,640 \\
Intraventriküler & 0 & $1(\% 5)$ & 0,253 \\
Klinoid & $1(\% 1,7)$ & $1(\% 5)$ & 0,445 \\
Konveksite & $16(\% 27,1)$ & $7(\% 35)$ & 0,573 \\
Olfaktör oluk & $8(\% 13,6)$ & $2(\% 10)$ & 0,679 \\
Parasagittal & $10(\% 16,9)$ & $4(\% 20)$ & 0,744 \\
Petroklival & $1(\% 1,7)$ & $1(\% 5)$ & 0,445 \\
Planum sfenoidale & $1(\% 1,7)$ & 0 & 1,00 \\
Sfenoid kanat & $12(\% 20,3)$ & $4(\% 20)$ & 0,974 \\
Serebellopontin köşe & $2(\% 3,4)$ & 0 & 1,00 \\
Tentorial & $1(\% 1,7)$ & 0 & 1,00 \\
Tuberkulum sella & $4(\% 6,8)$ & 0 & 0,567 \\
& & & \\
\hline
\end{tabular}

Olguların kan grubu analizlerinde A Rh (+) grubuna ait olguların $(n=36)$ ilk sırada yer aldığı görülürken, bu sonuçların histopatolojik grade dağılımı incelendi (Tablo 3).

Tablo 3. Olguların kan grupları ile tümör histopatolojik derecelendirilmesinin karşılaştırılması.

\begin{tabular}{llll}
\hline & \multicolumn{2}{c}{ Histopatolojik Grade } & \\
\cline { 2 - 3 } Kan Grubu & $\begin{array}{l}\text { Grade I } \\
\mathbf{n}(\%)\end{array}$ & Grade II & \\
\hline A (-) & $3(\% 5,1)$ & 0 & \\
A (+) & $24(\% 40,7)$ & $12(\% 60)$ & \\
AB (+) & $1(\% 1,7)$ & $2(\% 10)$ & \\
B (-) & $1(\% 1,7)$ & 0 & 0,234 \\
B (+) & $9(\% 15,3)$ & $2(\% 10)$ & \\
O (-) & $2(\% 3,4)$ & 0 & \\
O (+) & $19(\% 32,2)$ & $4(\% 20)$ & \\
\hline
\end{tabular}

Sigara kullanımının histopatolojik grade ile ilişkisine bakıldığında ise, $56(\% 70,9)$ olgunun sigara kullanmadığı belirlenirken, $23(\% 29,1)$ olgunun kullandığı saptandı (Tablo 4).

Preoperatif radyolojik değerlendirme sonucu, peritümöral ödem varlığı ve lokalizasyon ilişkisi değerlendirildi (Tablo 5). Özellikle sfenoid kanat menin- giomlarında peritümöral ödemin daha fazla olduğu saptandı $(p<0,05)$.

Tablo 4. Sigara kullanım öyküsü ile tümör histopatolojisi arasındaki ilişkinin değerlendirilmesine ait sonuçlar.

\begin{tabular}{llll}
\hline \multirow{2}{*}{ Sigara Kullanım Öyküsü } & \multicolumn{2}{c}{ Histopatolojik Grade } & \\
\cline { 2 - 3 } & $\begin{array}{l}\text { Grade I } \\
\mathbf{n}(\%)\end{array}$ & Grade II & \\
\hline Var & $18(\% 30,5)$ & $5(\% 25)$ & \\
Yok & $41(\% 69,5)$ & $15(\% 75)$ & 0,639 \\
\hline
\end{tabular}

Tablo 5. Olguların peritümöral ödem ve tümör yerleşimi arasındaki ilişkinin değerlendirilmesi.

\begin{tabular}{llll}
\hline \multirow{2}{*}{ Lokalizasyon } & \multicolumn{2}{c}{ Peritümoral Ödem } & \\
\cline { 2 - 3 } & $\begin{array}{l}\text { Var } \\
\text { n (\%) }\end{array}$ & Yok & \\
\hline Falks & $2(\% 4,5)$ & $4(\% 11,4)$ & 0,398 \\
Intraventriküler & $1(\% 2,3)$ & 0 & 1,000 \\
Klinoid & $1(\% 2,3)$ & $1(\% 2,9)$ & 1,000 \\
Konveksite & $15(\% 34,1)$ & $8(\% 22,9)$ & 0,275 \\
Olfaktör oluk & $4(\% 9,1)$ & $6(\% 17,1)$ & 0,285 \\
Parasagittal & $7(\% 15,9)$ & $7(\% 20)$ & 0,636 \\
Petroklival & 0 & $2(\% 5,7)$ & 0,193 \\
Planum sfenoidale & 0 & $1(\% 2,9)$ & 0,450 \\
Sfenoid kanat & $15(\% 34,1)$ & $1(\% 2,9)$ & 0,001 \\
Serebellopontin köşe & 0 & $2(\% 5,7)$ & 0,193 \\
Tentorial & $1(\% 2,3)$ & 0 & 1,00 \\
Tuberkulum sella & $1(\% 2,3)$ & $3(\% 8,6)$ & 0,317 \\
& & & \\
\hline
\end{tabular}

Opere edilen olguların cerrahi rezeksiyon derecelendirmeleri Simpson ve Kobayashi cerrahi gradelemesine göre yapıld ${ }^{3,4}$. Simpson gradelemesine göre (3), $50(\% 63,2)$ olguya grade I, 26'sına $(\% 32,9)$ grade II, 3 'üne $(\% 3,9)$ grade IV cerrahi rezeksiyon yapıldığı anlaşıldı.

Olguların takipleri sırasında toplam $9(\% 11,4)$ olguda nüks görülürken, $70(\% 88,6)$ olguda saptanmadı. Cerrahi rezeksiyon derecesi ile nüks olgular arasında yapılan değerlendirmede Simpson grade IV ve Kobayashi grade IVA ve IVB rezeksiyon yapılan olguların tümünde nüks saptandığı anlaşıldı (Tablo 6).

Nüks olgular ile histopatolojik alt tip arasındaki ilişki incelendiğinde, nüks eden $7(\% 77,7)$ olgunun grade II, $2(\% 33,3)$ olgunun ise grade I meningiom olduğu 
görüldü. Nüks olguların lokalizasyonu incelendiğinde, $4(\% 44,4)$ olgu sfenoid kanat, 2'si $(\% 22,2)$ parasagittal, $1^{\prime} i(\% 11,1)$ tuberkulum sella, $1^{\prime} i(\% 11,1)$ ise intraventriküler meningiom tanılarına sahip olduğu görüldü.

Tablo 6. Olguların nüks oranları ile cerrahi rezeksiyon grade'leri arasındaki ilişkinin istatistiksel olarak değerlendirilmesinin sonuçları.

\begin{tabular}{|c|c|c|c|c|}
\hline \multirow[b]{2}{*}{ Cerrahi Rezeksiyon } & \multirow[b]{2}{*}{ Grade } & \multicolumn{2}{|c|}{ Nüks } & \multirow[b]{2}{*}{$\mathbf{p}$} \\
\hline & & $\begin{array}{l}\text { Var } \\
\text { n (\%) }\end{array}$ & $\begin{array}{l}\text { Yok } \\
\text { n (\%) }\end{array}$ & \\
\hline \multirow[t]{3}{*}{ Simpson Grade } & Grade I & $4(44,4)$ & $46(65,7)$ & \\
\hline & Grade II & $2(22,2)$ & $24(34,3)$ & \\
\hline & Grade IV & $3(33,3)$ & 0 & 0,442 \\
\hline \multirow[t]{4}{*}{ Kobayashi Grade } & Grade I & $4(44,4)$ & $46(65,7)$ & \\
\hline & Grade II & $2(22,2)$ & $11(34,3)$ & \\
\hline & Grade IV A & $2(22,2)$ & 0 & \\
\hline & Grade IV B & $1(11,1)$ & 0 & 0,649 \\
\hline
\end{tabular}

\section{TARTIŞMA}

Moleküler genetiğin ilerlemesi olasılıkla meningiom patogenezinde en önemli başarı olmakla birlikte, meningiom biyolojisinin anlaşılmasına dair son dekatda önemli araştırmalar gerçekleştirilerek kayda değer ilerlemeler kaydedilmiştir ${ }^{5,6}$. Histopatolojik olarak, en önemli yenilik şüphesiz, 2000 yılında Dünya Sağlık Örgütü tarafından ortaya konan ve 2016 yılında yenden düzenlenen sınıflama olmuştur?

Yeni sınıflandırma şemasındaki meningiom derecelendirme ölçütleri daha kesin ve objektiftir. Bu sayede tümör rekürrensi ve agresif davranışın tahmininde tutarlılık geliştirilebilmektedir.

$\mathrm{Bu}$ araştırmada, son yıllarda elde edilen meningiom biyopatogenezindeki gelişmelere ek meningiom sınıflamasının, etiyolojide yer alabilecek predispozan faktörleri, cerrahi rezeksiyon derecesinin tümör nüksü üzerine etkisini, tümör lokalizasyonu ile peritümoral ödem arasındaki ilişkinin değerlendirilmesi amaçlandı.

Meningiomlar, muhtelif biyolojik, histopatolojik ve genetik özelliklere sahip olup, en sık görülen primer intrakranial tümörlerdir ${ }^{8}$. Tarihsel süreç göz önüne alındığında, ilk olarak meningiomlarda cerrahi yaklaşımlar ve etiyolojik nedenler üzerinde durulmuştur ${ }^{9,10}$. Meningiomlar, orta ve ileri yaş erişkinlerde görülen ekstra-aksiyel yerleşimli beyin tümörleri olup, kadınlarda görülme sıklığı erkeklerden daha fazladır ${ }^{11}$.

Çalışmamızda da literatür ile uyumlu olarak, olguların \%70,9'unu kadınlardan oluştuğu görüldü. Olgulara ait yaş dağılımın ise 23 ile 78 yıl arasında ve ortalama 52,9 yıl olduğu hesaplandı.

Sigara kullanımının menigiom gelişimi üzerine etkisine yönelik yapılan çalışmalarda, sigara kullanımının meningiom oluşumunda etkisinin olmadığı saptanmıştır ${ }^{12,13}$.

Araştırma sonuçlarından elde ettiğimiz bulgular arasında Grade I olgularda sigara kullanımının \%30,5 oranında ve Grade II olgularda ise bu oranın \%25’e düştüğü raporlandı. Ancak bu sonuçların istatistiksel olarak değerlendirilmesi neticesinde anlamlı bir fark görülmediği anlaşıldı ( $p>0,05)$.

Alkol kullanım öyküsü ile meningiom gelişimi arasındaki ilişkiye yönelik gerçekleştirilen araştırmalar içerisinde, Allés ve ark. ${ }^{14}$, alkol tüketiminin anılan tümör gelişimi ile ilişkilendirilemediğini bildirmişlerdir.

Araştırmamızda, dosya arşiv taramasının temel alındığı geriye yönelik çalışma tasarımına sahip olduğundan, tüm olguların alkol kullanım öyküsüne ait veriler, tam olmadığından, bu veriye yönelik istatistiksel değerlendirme gerçekleştirilememiştir.

Meningiomlar ile $A B O$ kan grupları arasındaki ilişkiye ait kanıt değeri yüksek çalışmalara nadir rastlandığından, kan grupları ile tümörler arasındaki korelasyonun açık olmadığı görülmektedir. Buna ilişkin Mehrazin'in ${ }^{15}$ gerçekleştirdiği araştırmada, olguların \%35,9'unun A Rh (+), \%30,7'sinin 0 Rh (+) ve $\% 23,9$ 'unun ise $B \mathrm{Rh}(+)$ kan grubuna sahip olduğunu ancak hiçbir kan grubu ile meningiomların arasında istatistiksel olarak bir ilişkiye rastlanmadığı bildirilmektedir. 
Değerlendirdiğimiz olgularda ise \%45,6 A Rh (+), $\% 29,10 \mathrm{Rh}(+)$ ve \%13,9 B Rh (+) kan grubuna sahip oldukları gözlemlenirken, tıpkı Mehrazin'e ${ }^{15}$ ait çalışmada olduğu gibi, meningiom ile ABO kan grupları ilişkisi istatistiksel olarak anlamlı görülmemiştir $(p>0,05)$.

Sigara, alkol ve $A B O$ kan gruplarının tümör gelişimi üzerine etkilerine ait mekanizmalar net olmasa da meningiom lokalizasyonu, klinik bulgular ve cerrahi planlama açısından önem göstermektedir ${ }^{16,17}$.

Chirstensen ve ark.'nın ${ }^{18}$ yaptığı çalışmada, meningiom tanılı olgularda tümörlerin $\% 25$ 'i parasagittal/ falks, \%19'u konveksite, \%17'si sfenoid kanat, \%9'u suprasellar, \%8'i olfaktor oluk yerleşimli olarak rapor edilmiştir ${ }^{18}$. Yapılan benzer bir çalışmada ise olguların \%34,7'sinde konveksite, \%22,2'sinde parasagittal, $\% 17$ 'sinde sfenoid kanat ve \%5,1'inde meningiomların, intraventriküler yerleşimli olduğu raporlanmaktadır ${ }^{19}$. Buna ek olarak, Mascarenhas ve ark. ${ }^{20}$, meningiom tanılı olgularda tümörün $\% 29$ oranında kafa tabanı yerleşimli, \%28 konveksite, \%17 parasagittal ve \%11 falks/tentorial yerleşimli olduğunu belirtmektedirler ${ }^{20}$.

Değerlendirmeye aldığımız meningiom olgularında ise tümör lokalizasyonlarının \%25,3 konveksite, \%20 ,3 sfenoid kanat, \%16,5 parasagittal ve \%12,7 olfaktor oluk yerleşimli olduğu anlaşıldı. Buna karşılık diğer lokalizasyondaki meningiomların daha az oranda görüldüğü belirlendi.

Peritümöral ödem, mortalite ve morbidite gelişiminde en az tümörün kitle etkisi kadar önemlidir ${ }^{21}$. Peritümöral ödem ile özellikle büyük hacimli tümörler, vasküler yapılara bası, tümör lokalizasyonu, histolojik alt tip ve VEGF ile arasında ilişki kurulmuştur ${ }^{22,23}$. Pereira-Filho ve ark.'nın ${ }^{24} 74$ olguluk meningiom serisinde, 52 (\%70) olguda peritümöral ödem saptanmış olup, 22'sinde (\%30) peritümöral ödeme rastlanmamıştır. Aynı çalışmada, peritümöral ödem saptanan olguların $\% 17,5^{\prime} i$ sfenoid kanat, $\% 14,8^{\prime} i$ konveksite, $\% 13,5$ 'i olfaktor oluk yerleşimli olup, histopatolojik alt tiplerine bakıldığında \%37'si transizyonel, \%27,7'si meningotelyal, \%11,1'i fibroblastik tip olduğu bulunmuştur. Çalışmamızda ise olguların 44'ünde $(\% 55,7)$ peritümöral ödeme rastlanırken, $35^{\prime}$ inde $(\% 44,3)$ rastlanmamıştır. Peritümöral ödem saptanan olguların 15'i $(\% 34,1)$ konveksite, 15'i $(\% 34,1)$ sfenoid kanat, 7'si $(\% 15,9)$ parasagittal bölge lokalizasyonlu olduğu görüldü. Histopatolojik alt tipler incelendiğinde, $24(\% 54,5)$ olgunun transizyonel, $13(\% 29,5)$ olgunun atipik, 4 (\%9) olgunun ise meningotelyal olduğu, diğer subtiplerde daha az oranda görüldüğü saptandı. Çalışmamızda da bulgularımız, sfenoid kanat lokalizasyonu $(p<0,05)$ hariç, diğer tümör lokalizasyonları ve histopatalojik subtipler ile peritümöral ödem arasında ilişki istatistiksel olarak anlamlı görülmemiştir $(p>0,05)$.

Meningiomlarda cerrahinin boyutu nüks oranını etkileyen en önemli parametredir ${ }^{17,25}$. Simpson ve ark.'nın ${ }^{3}$ araştırmasında, 90 olguya grade I rezeksiyon yapılmış ve bu olguların takipleri sonucunda \%9 oranında nüks saptanmıştır. Yüz on dört olguya grade II rezeksiyon yapılmış, takiplerinde ise \%19 nüks saptanmış, 24 olguya grade III rezeksiyon yapılmış ve takiplerinde \%29 nüks görülmüş, 51 olguya grade IV rezeksiyon yapılmış, takiplerinde ise \%44 oranında nüks saptanmıştır. Chan ve ark. ${ }^{26}$ ise benzer sınıflama sistemini kullanarak gerçekleştirdikleri araştırmalarında, grade I rezeksiyon yapılan olguların \%11'inde, grade II rezeksiyon yapılan olguların $\% 22$ 'sinde, grade III rezeksiyon yapılan olguların \%50'sinde, grade IV rezeksiyon yapılan olguların \%37'sinde, grade V yapılan olguların ise $\% 100$ 'ünde takipleri esnasında nüks saptandığını ileri sürmüşlerdir.

Bizim araştırma sonuçlarımız Simpson Cerrahi Gradelemesine göre değerlendirildiğinde, $50(\% 63,5)$ olguya grade I, $26(\% 32,9)$ olguya grade II, 3'üne $(\% 3,9)$ grade IV rezeksiyon yapıldı. Takiplerimiz sırasında $9(\% 11,4)$ olguda nüks saptandı. Nüks saptanan 4 $(\% 44,4)$ olguda grade I rezeksiyon, $2(\% 22,2)$ olguda grade II rezeksiyon, $3(\% 33,3)$ olguda ise grade IV rezeksiyon yapıldığı görüldü.

1957 yılında sunulan Simpson Cerrahi Sınıflaması ${ }^{3}$, Kobayashi ve ark. ${ }^{4}$ tarafından mikroskobik cerrahi çı- 
karım genişliğine göre, yeniden düzenlenerek 1992 yılında literatüre kazandırılmıştır ${ }^{27}$. Bu sınıflamaya göre tümör dokusunun invaze kemik ve dural dokular ile mikroskobik olarak eksizyonunun en uygun cerrahi yöntem olacağı ve Kobayashi Grade I rezeksiyonda, tümör nüks oranlarının daha az oranda görülebileceği ileri sürülmektedir.

Sonuçlarımızın Kobayashi Cerrahi Sınıflamasına göre değerlendirilmesi sonrasında olguların 50 $(\% 63,3)$ 'sine grade I, 26'sına $(\% 32,9)$ grade II, ikisine $(\% 2,6)$ grade IVA ve birine $(\% 1,3)$ grade IVB rezeksiyon uygulandığı anlaşıldı. Olguların takipleri sırasında, nüks belirlenen dokuz olgunun, dördüne $(\% 44,4)$ grade I, ikisine $(\% 22,2)$ grade II, ikisine $(\% 22,2)$ grade IVA, birine $(\% 11,1)$ ise grade IVB cerrahi rezeksiyon yapıldığı saptandı. Yaptığımız çalışmada, cerrahi rezeksiyon derecesi ile tümör nüksü arasında istatistiksel olarak anlamlı ilişki bulunmamış olsa bile grade IV cerrahi uygulanan olguların tümünde nüks saptandığı görüldü $(p>0.05)$.

Tümör nüksünü etkileyen diğer önemli nedenlerden biri ise histopatalojik alt tiptir ${ }^{28}$. Jaaskelainen ve ark. ${ }^{29}$, 936 olguluk serilerinde, olguların $\% 94,3$ 'ü grade I, $\% 4,7$ 'si grade II, \%1'i grade III olarak saptanmış olup, takipler sırasında grade I olanların \%3'ünde, grade II olguların \%38'inde, grade III olguların ise \%78'inde nüks bulunmuştur. Ildan ve ark. ${ }^{30}, 137$ olguluk serisinde ise olguların 130'u grade I, 6'sı ise grade II ve III saptanmış olup, grade I meningiomların \%7,6'sında, grade II ve III meningimların ise $\% 100$ 'ünde nüks saptamışlardır.

Araştırma sonuçlarımızın değerlendirilmesi sırasında, incelenmeye alınan olguların $\% 74,4$ 'ü grade I, $\% 25,3$ 'ünün grade II meningiom olduğu ve grade I meningiomlu olguların \%66,1'lik oranda transizyonel, $\% 22$ oranda meningotelyal, diğer alt tiplerin ise daha az oranlarda görüldüğü anlaşılmaktadır. Grade II meningiomların, $\% 80$ 'i atipik, $\% 20$ 'si berrak hücreli ve $\% 20$ 'si kordoid tip olarak saptandı. Nüks olgularının $\% 55,5^{\prime}$ i grade II, $\% 44,4$ 'ü grade I meningiom olarak hesaplandı. Bu bulgular sonrasında grade II meningiomlarda nüks oranının fazla olduğu literatür ile ben- zerlik göstermesine rağmen, bu sonucun istatistiksel olarak anlamlı olmadığı belirlendi $(p>0,05)$.

\section{SONUÇ}

Çalışmamızda meningiomların biyolojik davranış ve prognozunda rol alabilecek etkenler tartışıldı. Özellikle meningiomlarda histopatalojik alt tip ve cerrahi rezeksiyon derecesinin prognozda önemli rol aldığı saptandı. Ayrıca tümör lokalizasyonunun ve peritümöral ödem varlığının meningioma prognozunda ve biyolojik davranışa etki edebileceği düşünüldü. Ortaya koymaya çalıştığımızın bulguların, daha geniş seriler ile yapılacak çalışmalar ile desteklenmesi gerektiği düşüncesine varıldı.

\section{KAYNAKLAR}

1. Claus EB, Bondy ML, Shildkraut JM, Wiemels JL, Wrensch M, Black PM. Epidemyology of intracranial meningioma. Neurosurgery. 2005;57(6):1088-95.

https://doi.org/10.1227/01.NEU.0000188281.91351.B9

2. Perry A, Guthmann H. David, Reifenberger Guido. Molecular pathogenesis meningioma. Journal of Neuro-Oncology. 2004;70(2):183-202.

https://doi.org/10.1007/s11060-004-2749-0

3. Simpson $D$. The recurrence of intracranial meningiomas after surgical treatment. J Neurol Neurosurgery Psychiatry. 1957;20:22-39.

https://doi.org/10.1136/jnnp.20.1.22

4. Kobayashi K, Okudera H, Tanaka Y. Surgical considerations on skull base meningiomas. Presented at First International Skull Base Congress, Hanover, Germany, 18 June 1992.

5. Fukushima S, Yamashita S, Kobayashi H, Takami H, Fukuoka K, Nakamura T, et al. Intracranial Germ Cell Tumor Genome Analysis Consortium (The iGCTConsortium). Genome-wide methylation profiles in primary intracranial germ cell tumors indicate a primordial germ cell origin for germinomas. Acta Neuropathol. 2017;133(3):445-62. https://doi.org/10.1007/s00401-017-1673-2

6. Karaarslan N, Gurbuz MS, Caliskan T, Ayan E, Aker FV, Berkman MZ. The Effect of Matrix Metalloproteinase-3 on the Prognosis and Biological Behaviour of Meningiomas. Turk Neurosurg. 2016;26(5):678-83.

7. Louis DN, Perry A, Reifenberger G, von Deimling A, FigarellaBranger D, Cavenee WK, et al. The 2016 World Health Organization Classification of Tumors of the Central Nervous System: a summary. Acta Neuropathol. 2016;131(6):803-20. https://doi.org/10.1007/s00401-016-1545-1

8. Cushing $\mathrm{H}$, Eisenhardt L. Meningiomas: Their classification, regional behavior, life history, and result. Springfield, IL: Hafner Publishing Co. 1938: p.49-224.

9. Baser ME, R Evans DG, Guthmann DH. Neurofibromatosis 2. Curr Opin Neurol. 2003;16(1):27-33.

https://doi.org/10.1097/00019052-200302000-00004

10. Radner H, Katenkamp D, Reifenberger G, Deckert M, Pietsch 
T, Wiestler OD. New Developments in the pathology of skull base tumors. Vircjows Arc. 2001;438(4):321-35. https://doi.org/10.1007/s004280100395

11. CBTRUS: Statistical Report: Primary Brain Tumors in the United States, 1998-2002. Chicago: Central Brain Tumors Registry of the United States, 2005.

12. Preston MS, Mack W, Henderson BE. Gliomas and meningiomas in man in Los Angeles Country: investigation of exposures to N-nitroso compounds. IARC Sci Publ. 1991;(105): 197-203.

13. Ryan P, Lee MW, North JB, McMicheal AJ. Risk factors for tumors of the brain and meninges: result from the Adelaide adult brain tumor study. Int J Cancer. 1992;51(1):20-7. https://doi.org/10.1002/ijc.2910510105

14. Allès B, Pouchieu C, Gruber A, Lebailly P, Loiseau H, FabbroPeray $P$, et al. Dietary and Alcohol Intake and Central Nervous System Tumors in Adults: Results of the CERENAT Multicenter Case-Control Study. Neuroepidemiology. 2016;47(34):145-54. https://doi.org/10.1159/000450580

15. Mehrazin M. ABO Blood Group Frequency and Brain Tumors. Asian Pacific J Cancer. 2006;7(4):582-4.

16. Splavski B, Hadzic E, Bagic I, Vrtaric V, Splavski B Jr. Simple Tumor Localization Scale for Estimating Management Outcome of Intracranial Meningioma. World Neurosurg. 2017;104:876-82. https://doi.org/10.1016/j.wneu.2017.05.039

17. Black P, Morokoff A, Zauberman J, Claus E, Carroll R. Meningiomas: Science and Surgery. Clin Neurosurg. 2007;54:91-9.

18. Christensen HC, Kosteljanetz M, Johansen C. Incidence of gliomas and meningiomas in Denmark, 1943 to 1997. Neurosurgery. 2003;52(6):1327-34.

https://doi.org/10.1227/01.NEU.0000064802.46759.53

19. Chamberlain MC. Meningiomas. Curr Treat Options Neurol. 2001;3(1):67-76. https://doi.org/10.1007/s11940-001-0025-6

20. Mascarenhas L, Fonseca $M$, Honavar $M$, Romao $H$, Resende $M$, Rocha Vaz A. Analysis of the influence of the variable size on the characteristics and behavior of meningiomas. Neurocirurgia. 2005;16(6):486-91. https://doi.org/10.1016/S1130-1473(05)70376-6

21. Lampl Y, Barak Y, Achiron A, Sarova-Pinchas I. Intracranial meningiomas: correlation of peritumoral edema and psychiatric disturbances. Psychiatry Res. 1995;58(2):177-80. https://doi.org/10.1016/0165-1781(95)02586-L

22. Louis DN, Hamilton AJ, Sobel RA, Ojemann RG. Pseudo psammomatuos meningioma with elevated serum carcinoembryonic antigen: a true secretory meningioma. Case report. J Neurosurg. 1991;74(1):129-32. https://doi.org/10.3171/jns.1991.74.1.0129

23. Tomita $\mathrm{Y}$, Ono $\mathrm{Y}$, Matsumoto $\mathrm{K}$, Ohmoto T. Peritumoral brain edema intracranial meningiomas: effects of radiological and histological factors. Neurosurgery. 2001;49(5):1046-51.

24. Pereira-Filho NA, Soares FB, Chemale IV, Coutinho LMB. Peritumoral brain edema in intracranial meningiomas. Arq Neuropsiquiatr. 2010;68(3):346-9. https://doi.org/10.1590/S0004-282X2010000300003

25. Ryu HS, Moon KS, Lee KH, Jang WY, Jung TY, Kim IY, et al. Recurred Intracranial Meningioma: A Retrospective Analysis for Treatment Outcome and Prognostic Factor. Brain Tumor Res Treat. 2017;5(2):54-63. https://doi.org/10.14791/btrt.2017.5.2.54

26. Nanda A, Thakur JD, Sonig A, Missios S. Microsurgical resectability, outcomes, and tumor control in meningiomas occupying the cavernous sinus. J Neurosurg. 2016;125(2):378-92. https://doi.org/10.3171/2015.3.JNS142494

27. Chan RC, Thampson GB. Morbidity, mortality and quality of life following surgery for cranial meningiomas. A retrospective studyin 257 cases. J Neurosurg. 1984;60(1):52-60. https://doi.org/10.3171/jns.1984.60.1.0052

28. Yoo-Jin K, Ketter R, Henn W, Zang KD, Steudel WI, Feiden W. Histopathologic indicators of recurrence in meningiomas: correlation with clinical and genetic parameters. Virchows Arch. 2006;449(5):529-38. https://doi.org/10.1007/s00428-006-0285-3

29. Jaaskelainen J, Haltia M, Servo A. Atypical and anaplastic meningiomas: radiology, surgery, radiotherapy and outcome. Surg Neurol. 1986;25(3):233-42. https://doi.org/10.1016/0090-3019(86)90233-8

30. Ildan F, Erman T, Gocer D, Tuna M, Bagdatoglu H, Cetinalp $\mathrm{E}$, et al. Predicting the Probability of Meningioma Recurrence in the Preoperative and Early Postoperative Period: A Multivariate Analysis in teh Midterm Follow-Up. Skull Base. 2007;17(3):157-71. https://doi.org/10.1055/s-2007-970554 